\title{
Improving Teaching Quality to Cultivate Innovative Talents
}

\author{
Zhi-Xia JIANG ${ }^{1, a}$, Pin-Chao MENG ${ }^{1, b,{ }^{*}}$, San-Zhi SHI ${ }^{1, c}$ \\ ${ }^{1}$ College of Science,Changchun University of Science and Technology, Changchun, Jilin, \\ 130022, China \\ azhixia_jiang@126.com, 'bmengpc@cust.edu.cn, cshisanzhi@sina.com \\ *Corresponding author
}

Keywords: Innovative, Teaching quality, Research-oriented teaching.

\begin{abstract}
From four aspects introduce the experience of improving the teaching quality to cultivate innovative talents in Changchun University of Science and Technology all the time. Specify student-centered to carry out the research-oriented teaching, teachers as a fundamental, teaching and research in parallel, carry out course construction actively. The teachers must understand fully the important role of teaching work, pay attention to the teaching and research activities, and improve the teaching level constantly. The higher school must sound system to promote higher education connotation development.
\end{abstract}

\section{Introduction}

Higher education act of the People's Republic of China stipulated explicitly: "The task of higher education is to cultivate senior specialized talents with innovative spirit and practice ability, develop science and technology culture, promote the construction of socialist modernization."[1] Innovative talents have a wide range of knowledge and solid knowledge structure, innovation consciousness and ability, and have the capability of organization and coordination management. Refers to those with excellent quality, by innovation practice achieved outstanding achievements in scientific research and social practice, make positive contribution for human understanding and transforming the world, for the development of society, economy, science and technology progress.

In order to achieve this task, Department of Applied Mathematics in Changchun University of Science and Technology, in the work of teaching innovation, in terms of teaching, teaching methods, means and teaching content reform actively, good results have been achieved.

\section{Student-centered to carry Out the Research-Oriented Teaching}

In recent years, in order to develop students' research ability and innovation ability, the more attention paid to the research-oriented teaching method, case teaching, based on the problem of learning and learning based on problem solving teaching method develop in university teaching practice [2]. Research-oriented teaching methods can create the teaching situation of close to reality, stimulate and enhance students' interest in learning and ability to adapt work, cases and problems as the core, Cause the knowledge of learning and consultation, and thus reveal the complexity of the problem. Interest is The power of driving The student active learning, to attach importance to cultivate The students' learning motivation, learning motivation mainly includes: The cognition of The study, in recognition of The importance of studying at The university of inner; In learning emotions, that is, from the study get happiness and a sense of achievement; Intention of learning, that is, learning initiative, self-control and firmness. In the popularization of education stage, students' interests more personalized more diversified value orientation. Economic and social development has diversified demand level of college students. The headmaster, professor and doctoral supervisor of North China University of Technology, Wang Xiaochun talking about layered shunt classification training mode in special emphasis on: student - centered, according to their aptitude. In order to achieve the training objectives of different, can create layered teaching of basic course curriculum 
system, teaching specialized courses in the curriculum system, points across the professional course system of module teaching. The school personnel training mode, mainly is to realize the concept innovation, model innovation, evaluation system innovation and management innovation.

Teaching must be a student - oriented, the use of the open - ended, the study - the discussion the pattern, the inquiry - -based teaching. Highlight the personality cultivation of new ideas, pay attention to than with each individual, according to their aptitude, and improve the occasion, to establish "stratified teaching, shunt, classification success" of new ideas. "To manage as the center" to "focus on the needs of students," transform "give priority to in order to teach" to "according to their aptitude". Inspires guide in the teaching process, and realize the interaction between teachers and students. The research-oriented teaching Need to be active classroom atmosphere [3]. With participatory teaching, encouraging students to participate in the study, teachers design some related to basic teaching contents but need further exploration, encourage students themselves to find relevant materials, adopting the methods such as group discussions and big operation, puts forward all kinds of the methods and ideas to solve the problem. In class to elaborate design to be able to stimulate and guide the students' thinking, for students to set aside the appropriate thinking space.

In addition, in order to improve the teaching quality of whole students must carry out standardized teaching management, course construction planning, and organization of teaching science. Have a scientific and standardized teaching outline, each semester calendar, teaching activity records, the system of the teachers listen to each other and record, the new teachers' teaching demonstration system and complete the course construction of archives.

\section{Teachers as a Fundamental, Optimize the Teaching Team}

Improve the teaching quality of education, the teacher is fundamental. Department of Applied Mathematics in Changchun University of Science and Technology has the characteristics of information and computing Science specialty, at the provincial level has a high teaching level, age, educational background, professional title structure is reasonable, full of dedication and innovative teaching team. Full-time teachers with 24 people, including senior title of professional teachers accounted for $62.5 \%$; Has a doctorate in teachers accounted for $79.2 \%$; Full-time teachers are a "ministry of education of institutions of higher learning of university mathematic teaching guidance committee", the winner of a "special government allowances of the state council", a "Jilin province teaching masters" and two "Jilin province outstanding teachers", a "Jilin province young and middle-aged professional and technical personnel with outstanding contribution", a " Fok Ying-tung education foundation for young teachers award", the two "the advanced individual of Jilin province education system the teacher's ethics", "Jilin province site statistics institute vice director of" a, "Jilin province society for industrial and applied mathematics" two deputy director and a director, vice director of a "Jilin province mathematical society" and the vice secretary-general of a; Part-time teachers there are 12 people, including senior title teachers accounted for $83.3 \%$; There are two PhD teachers. High levels of teachers can satisfy the teaching conditions, guiding practice and graduate students.

To improve the quality of teaching must optimize the teaching team. Changchun university of science and technology by participating in the "national game" the micro course teaching in college and universities, such as "young teachers lecture contest" competition and selection "youth teaching pacesetter", "advanced individual teaching, management and service,", "the quality of teaching excellence award honorary titles such as" promoting young teachers to improve teaching level, applied mathematics has also been through training, learning, meeting the previous work of methods such as a constant reminder of teachers' introspection, understand courses related to the development direction and goal, in order to make greater progress. Exquisite teaching skills of teachers for the teaching methods and skills to improve teacher training system, include: evaluate the teaching effect, encourage cooperative learning in class, meet the needs of the students, understand the diversity of teaching and so on [4]. 


\section{Teaching and Research in Parallel, Pay Attention to the Improvement of Teaching Level}

Undergraduate education is the foundation of graduate education and the cultivation of talents selection, should be at the center of university education. Of the title of teachers in colleges and universities and a lot of performance appraisal are directly with scientific research, do scientific research, the thesis is an essential part of teachers' work. Teaching should be the first priority, however, must not deviate from the goal of teaching. Former President of Harvard University Drake Bork, also for American university undergraduate course education has carried on the profound reflection, including intense criticism. World university rankings, he thought, tend to focus on the scientific research level of a university, rather than the quality of teaching, if the normal four-year undergraduate course colleges and universities include, the overall situation is not optimistic. He analyzed in detail why university professor and a lack of multiple factors on undergraduate education, which is, undergraduate students as research of high quality quantitative and evaluation. He argues that improve the quality of undergraduate education is the way to return to university.

In late 2013, the ministry of education issued the opinions on deepening the reform of higher school science and technology evaluation, which lists the problems in the evaluation of university of science and technology: pay attention to quantity and does not pay attention to quality, pay attention to the form does not pay attention to content, pay attention to short-term does not pay attention to long-term phenomenon still exists; Single evaluation, quantitative evaluation standard, evaluation method of simplification, evaluation results utilitarian tendency are not fundamental change; Science and technology to support teaching and innovative talent training guide is not enough. In this opinion, also puts forward some concrete reform direction, and change in teacher appraisal, the income distribution to rely too much on and unreasonable use of academic papers, patent, projects, and funding for science and technology indexes such as number of practices, to reduce the excessive interest distribution and the evaluation results of science and technology association; Pay more attention to science and education combined with support personnel training.

With the improvement of teachers' scientific research ability, teachers have a more profound academic background, you can dare to some fuzzy concepts in traditional teaching content and incorrect theory to clarify and correct, to the analysis and calculation method are modified, do well in classroom teaching academic inverse problem are put forward. To deepen the depth of the basic teaching content, improve teaching academic and challenging.

Department of Applied Mathematics in Changchun University of Science and Technology teachers chaired or participated in national natural Science foundation and high-level project a total of 14, a total of 11 provincial projects; 104 scientific papers published articles, of which the SCI and EI retrieval 29 papers. Research-oriented teaching in the teaching work, adhere to the teaching and scientific research in parallel, through teaching, seminar, cognition practice, course design and graduation thesis in a variety of ways, with engineering practical problems as the center, attaches great importance to the background source and application of knowledge.

\section{Improve the Quality of Teaching, to Carry Out the Course Construction}

In 2003 the ministry of education issued a "about starting college teaching quality and teaching reform project construction work notice", request to establish all kinds of products, professional school, provincial, national levels curriculum system [5].The university teaching methods reform into "Quality project" project, the Quality Course, brand requirements are clear teaching method reform of evaluation index. Changchun university of science and mathematics courses of the existing course construction are: 2010 provincial excellent courses "Higher Mathematics", 2013 provincial excellent course "Probability Theory and Mathematical Statistics", in 2012 the fine course "Linear Algebra" field, 2011 provincial excellent course "Mathematical Model", in 2012 the provincial excellent course "Complex Variable Function and Integral Transform".

Construction of excellent courses is one of the common characteristics of emphasis on the combination of research and teaching. The excellent course construction goal is to "in the existing 
characteristics and advantages of professional disciplines, on the basis of the construction has the classic, classic, teachers teaching content, the classic teaching methods, teaching materials and first-class teaching management and so on the characteristic of demonstrative curriculum".

In a word, the university reform and innovation of teaching methods must be comprehensive planning, clear objectives, specific requirements. Listen to the teacher can use leaders at all levels and the teaching teams, strengthen teaching inspection system, take many forms, a variety of ways, through teaching information channel between managers, teachers, students, establish and improve the teaching quality monitoring system.

\section{Acknowledgement}

This research was financially supported by the Education Department of Jilin Province 2012.

\section{References}

[1] J. Qin, A.F. Wang, On cultivation of innovative talents of institution of higher education, Research in Teaching. 32 (2009) 13-17.

[2] H. Zhao, Study based teaching and college teaching methods research, Journal of Higher Education. 27(2006) 71-75.

[3] Y.S. Fan,Y.J. Yin,J.P. Chen,G.L. Guo, The implementation of research-based teaching innovation, China Higher Education. 5(2013) 23-25.

[4] Z.J. Liu, University's teaching method reform and innovation must be regarded. Research in Teaching. 33(2010) 33-37.

[5] C.J. Zhu, Z.B. Hu. Combining research and teaching promoting the construction of national elaborate courses, China Higher Education. 1(2013) 45-51. 